\title{
Evaluation of Some Spices Powder as Grain Protectant Against Pulse Beetle, Callosobruchus Chinensis (L.)
}

\author{
Md. Saiful Islam ${ }^{1,2}$, Md. Azizul Haque ${ }^{1}$, Kazi Shahanara Ahmed ${ }^{1}$, Md. Fuad Mondal ${ }^{3, *}$, \\ Chandra Kanta Dash ${ }^{3}$ \\ ${ }^{1}$ Department of Entomology, Bangladesh Agricultural University, Mymensingh-2202, Bangladesh \\ ${ }^{2}$ International Rice Research Institute, Bangladesh Office, Banani, Dhaka-1213, Bangladesh \\ ${ }^{3}$ Department of Entomology, Sylhet Agricultural University, Sylhet-3100, Bangladesh \\ *Corresponding Author: fuadentom@yahoo.com
}

Copyright @ 2013 Horizon Research Publishing All rights reserved.

\begin{abstract}
The biological activity of four spices powder namely black pepper (Piper nigrum L.), black cumin (Nigella sativa L.), methi (Trigonella foenum-graecum) and garlic (Allium sativum L.) was assessed on the basis of adult mortality, oviposition performance, adult emergence of pulse beetle Callosobruchus chinensis L, and seed damage and consequent weight loss of gram (Cicer arietinum) caused by this insect at $0.25 \mathrm{~g}, 0.50 \mathrm{~g}$ and $1.00 \mathrm{~g}$ powder $/ \mathrm{kg}$ gram seeds. All the tested spices powder showed significant effect on the above parameters. The highest adult mortality was recorded when gram seeds were treated with black pepper powder at $1.00 \mathrm{~g} / \mathrm{kg}$. whereas methi showed the least effect on adult mortality. Spices powder used in the experiment effectively controlled adult emergence by inhibiting oviposition and growth and development of life stages of pulse beetle. In all the treatments lowest number of adult emergence was obtained from gram seeds treated with black pepper at $1.00 \mathrm{~g} / \mathrm{kg}$ seeds. The highest weight loss was observed in control treated seeds followed by methi powder at $0.25 \mathrm{~g} / \mathrm{kg}$ gram seeds. Black pepper treated seeds showed the lowest seed weight loss followed by black cumin, garlic and methi. From this present study the toxicity of the spices powder were found in the order black pepper $>$ black cumin $>$ garlic $>$ methi.
\end{abstract}

Keywords Spices, Grain Protectant, Pulse Beetle, Gram Seed

\section{Introduction}

Pulse includes beans, peas, lentil, gram and other seeds of pod bearing plant belonging to the family leguminosae which contain high protein ranging from $20-40 \%$. It has been considered as poor man's meat for the under privileged people who cannot afford animal proteins. People of country like Bangladesh whose per capita animal protein consumption is very low can recover their dietary requirement by consuming protein from pulses. In 2009-2010 fiscal years, pulse grain production was 218 thousand metric tons [1] which is very low compared to cereal in Bangladesh. Apart from this, great portion of pulse seeds is damaged by stored grain pest [2]. The pulse beetles in the genus Callosobruchus (Coleoptera: Bruchidae) are economically important pests of stored pulse seeds [3-4]. It is responsible for an average of 32-64\% loss under storage in different parts of Asia and Africa [5-7]. It was reported that only in gram, 55-69\% weight loss of seed and 45.6-66.3\% loss in protein content was recorded by Callosobruchus chinensis L. [8].

Several methods are being used for controlling pulse beetle in the storage such as increase the storage temperature [9-10] use of microwave energy [11] biological control by larval parasitoids [12]. Pulse beetle is an internal feeder, so it difficult to control with insecticides. Moreover, it is also not advisable to mix insecticides with food grains due to the environmental health hazard and development of genetically resistance pest. Though fumigation has been the most effective method, but it cannot be practiced in rural areas because the storage structures are not airtight and these are mostly built inside residential areas. Since most farmers store their pulse grains in their homes, there is need to develop cheaper and safer alternatives for insect pest control, including plant based products.

Botanical plant products are environmentally safe, less hazardous and less expensive. The main advantage of botanical insecticides is that they can be easily used by farmers in hamlets and small scale industries. Among the botanical products spices are characterized by their flavour and odour due to the presence of aromatic oils. These volatile constituents can influence insect behavior [13] and some can act as botanical pesticides [14]. Essential oils of spices like anise, peppermint [15] ginger [16] and cinnamon [17] have been used in stored grain protection, and their constituents have also been evaluated for toxicity against stored product insect pests [18]. Recently spices were found as effective materials to protect pulse seeds from infestation of pulse beetle [19]. However research on spices as a grain protectant against pulse beetle 
in Bangladesh is scancity. Therefore, the present research work was undertaken to evaluate the efficacy of four spices powder against pulse beetle, $C$. chinensis as grain protectant on gram seeds (Cicer arietinum).

\section{Materials and Methods}

\subsection{Insect Culture}

Pulse beetles, Callosobruchus chinensis (L.) were reared by maintaining insects on gram seeds at room condition (average temperature $27^{\circ} \mathrm{C}$ and average relative humidity $70 \%$ ) in the Department of Entomology, Bangladesh Agricultural University, Mymensingh. Fifty pairs of adult male and female pulse beetles were placed in glass jar containing gram seeds. The jar was then covered with black cotton cloth and the beetles were allowed for free mating and oviposition for 7 days in the aforementioned environmental conditions in a dark place. The parent beetles were removed and pulses containing eggs were kept in a jar for further development and getting new adults. Rearing of the insects was continued for the whole experimental period.

\subsection{Plant Materials}

Four spices namely, Black pepper (Piper nigrum L.), Black cumin (Nigella sativa L.), Methi (Trigonella foenum-graecum ) and Garlic (Allium sativum L.) were assessed for their insecticidal potency against pulse beetle. They were collected from the local market of Mymensingh, Bangladesh. The collected test materials were dried in oven at $60^{\circ} \mathrm{C}$ for three to four days until they were reached constant weight and ready for powder preparation. Spice powders were prepared by pulverizing the oven dried seeds/cloves with the help of a steel blender. Then the dust was passed through a 25 -diameter sieve to obtain fine and uniform powder

\subsection{Sampling of Gram Seeds}

Gram (Cicer arietinum) Seeds were used in this experiment as host of pulse beetle and were collected from local market of Mymensingh. The seeds were completely free from insects and microorganisms. There were no other crop seeds and foreign materials in the seed lot. No insecticide was used on the gram seeds in the storage and before storing seeds was properly dried.

\subsection{Insect Bioassay}

Experiments were carried out in the laboratory of Entomology Department in Bangladesh Agricultural University. The spice powders were mixed with the gram seeds (20 g)@1.00,0.50 and $0.25 \mathrm{~g} / \mathrm{kg}$ gram seeds in separate petridishes ( $90 \mathrm{~mm}$ in diameter). Five pairs of newly emerged adult beetles were released into each Petridish containing treated seeds. Three replications were made for each treatment with control. The petridishes were kept in the in the room temperature without any disturbance. The efficacy of spice powders against pulse beetle was evaluated considering parental mortality, number of eggs, adult emergence and seed weight loss from treated and untreated seeds. Data on the parental mortality was recorded daily from $1^{\text {st }}$ day to $7^{\text {th }}$ day of release of the pulse beetles. After seven days total number of dead beetles were calculated

$$
\text { Mortality }=\frac{\text { Total number of dead pulse beetle }}{\text { Total number of pulse beetle released }} \times 100
$$

After seven days seeds were carefully examined using magnifying glass and seeds with eggs or without eggs were separated. After separation total number of egg bearing seeds and total number of eggs were recorded. After hatching the larvae of the beetle entered in the seeds and fed on the cotyledon where they pupate and came out as adult by making holes on the seed coat. The number of adult beetle emerged were counted daily from the date of first emergence and continued till last emergence. The pulse beetle started emerging after 24 days of release. Weight loss of pulse seeds caused by the feeding of pulse beetle was determined. The seeds were separated from dust and dead bodies of pulse beetle by winnowing. The clean seeds in each petridish were separately weighted. The weight loss of pulse seed was calculated by subtracting the final weight from initial weight. Then the weight loss was converted into percentage by the following formula:

$$
\text { Seed weight loss }(\%)=\frac{A-B}{A} \times 100
$$

Where, $\mathrm{A}=$ Initial weight; $\mathrm{B}=$ Final weight

\subsection{Statistical Analysis}

Data obtained were statistically analyzed in accordance with two factors Completely Randomized Design (CRD) and treatment means were compared by Duncan's Multiple Range Test (DMRT).

\section{Results and discussion}

\subsection{Effect of Spices Powder on the Adult Mortality Of Pulse Beetle}

All the tested spices powder showed significant effect on adult mortality of pulse beetle (Table 1). The mortality of pulse beetle increased gradually with the increase of doses of spices powder. The highest adult mortality $(83.0 \%)$ was observed in black pepper at $1.00 \mathrm{~g} / \mathrm{kg}$ gram seed. Black pepper at $0.50 \mathrm{~g} / \mathrm{kg}$ and black cumin at $1.00 \mathrm{~g} / \mathrm{kg}$ of gram seed also showed the similar effect like previous one. Among the tested spice powders, methi showed the least effect on adult mortality (30.0\%) at $0.25 \mathrm{~g} / \mathrm{kg}$ gram seeds. In control treatment, adult mortality was recorded only $20.0 \%$. 
Table 1. Effect of spices powder on the adult mortality (\%), oviposition and adult emergence of pulse beetle

\begin{tabular}{|c|c|c|c|c|}
\hline \multirow{2}{*}{ Spices } & $\begin{array}{c}\text { Doses } \\
(\mathrm{g} / \mathrm{kg})\end{array}$ & $\begin{array}{c}\text { Adult } \\
\text { mortality } \\
(\%)\end{array}$ & $\begin{array}{c}\text { No. of } \\
\text { laid eggs }\end{array}$ & $\begin{array}{c}\text { Adult } \\
\text { emergence } \\
(\%)\end{array}$ \\
\hline \multirow{3}{*}{$\begin{array}{c}\text { Black } \\
\text { pepper }\end{array}$} & 0.25 & $63.0 \mathrm{c}$ & $54.00 \mathrm{i}$ & $25.32 \mathrm{e}$ \\
\cline { 2 - 5 } & 0.50 & $79.0 \mathrm{a}$ & $51.00 \mathrm{j}$ & $19.01 \mathrm{f}$ \\
\cline { 2 - 5 } & 1.00 & $83.0 \mathrm{a}$ & $42.00 \mathrm{k}$ & $11.11 \mathrm{~g}$ \\
\hline \multirow{3}{*}{$\begin{array}{c}\text { Black } \\
\text { cumin }\end{array}$} & 0.25 & $49.0 \mathrm{~d}$ & $66.00 \mathrm{f}$ & $32.03 \mathrm{~d}$ \\
\cline { 2 - 5 } & 0.50 & $61.0 \mathrm{c}$ & $62.00 \mathrm{~g}$ & $26.33 \mathrm{e}$ \\
\hline \multirow{3}{*}{ Methi } & 1.00 & $79.0 \mathrm{a}$ & $58.00 \mathrm{~h}$ & $20.20 \mathrm{e} \mathrm{f}$ \\
\cline { 2 - 5 } & 0.25 & $30.0 \mathrm{e}$ & $80.00 \mathrm{bc}$ & $45.40 \mathrm{~b}$ \\
\cline { 2 - 5 } & 0.50 & $43.0 \mathrm{~d}$ & $78.00 \mathrm{c}$ & $40.05 \mathrm{c}$ \\
\hline \multirow{3}{*}{ Garlic } & 1.00 & $58.0 \mathrm{c}$ & $75.00 \mathrm{~d}$ & $31.32 \mathrm{~d}$ \\
\cline { 2 - 5 } & 0.25 & $49.0 \mathrm{~d}$ & $72.00 \mathrm{e}$ & $39.10 \mathrm{c}$ \\
\cline { 2 - 5 } & 0.50 & $61.0 \mathrm{c}$ & $70.00 \mathrm{e}$ & $32.20 \mathrm{~d}$ \\
\hline Control & 1.00 & $69.9 \mathrm{~b}$ & $67.00 \mathrm{f}$ & $21.21 \mathrm{e}$ \\
\hline
\end{tabular}

Means having different letter(s) within the column are significantly different at $\mathrm{P}<0.01$ by DMRT

The results in revealed the toxic effect of black pepper, black cumin, methi and garlic powder on adult pulse beetle C. chinensis $\mathrm{L}$ and the highest toxicity was evidenced in black pepper. This observation supported by the reports of Awoyinka [20], Scott [21], who reported that the seed extract of black pepper has the insecticidal property against the $C$. chinensis. Moreover ethyl acetate extracts of this spice seeds were reported to be toxic to Lepidopteran and Hymenopteran herbivorous insects [22-23]. The insecticidal activities of black pepper might be due to the presence of many potentials phyto-chemicals within it. The major components of black pepper fruit extracts such as piperine, caryophyllene and limonene are reported as having insecticidal properties. Chieng [24] used the extract of black pepper as bio-pesticide materials for the control of insect pest in a small scale. Chaubey [25] found the insecticidal properties of black cumin on stored pest $T$. Castaneum. Insecticidal activity of seeds and leaves extracts of methi against the stored product pests $\mathrm{T}$. castaneum and Acanthoscelides obtectus was found by Jerome [26]. Murthy and Amonkar [27] also found the insecticidal activities of garlic against the house fly, red palm weevil and potato tuber moth.

\subsection{Effect of Spices Powder on the Oviposition and Adult Ermergence of Pulse Beetle}

The female beetles laid eggs on the surface of gram seeds. The eggs looked like white dots clearly visible on the seeds. Numbers of eggs laid on seeds treated with different spices powder were found ranging from $0-10$ per seed in all treatments. The numbers of eggs laid on seeds of different treatments were significantly different. Number of eggs increased gradually with the decrease of doses (Table 1). The highest numbers of eggs were obtained in control treatment. Gram seeds treated $0.25 \mathrm{~g} / \mathrm{kg}$ and $0.50 \mathrm{~g} / \mathrm{kg}$ methi powder showed less effect on the ovipositon of pulse beetle. The lowest number of eggs was found in seed treated with black pepper at $1.00 \mathrm{~g} / \mathrm{kg}$. Adult beetle emerged from the gram seeds through the hole on the seed coat. The number of adult beetles emerged from gram seeds of different treatments showed a similar trend as observed in oviposition. The adult emergence of pulse beetle increased gradually with the decrease of dose of black pepper, black cumin, methi and garlic powders. The effect of different spice powders on number of adult emergence was statistically significant (Table 1). The highest number of adult emergence $(49.12 \%)$ was obtained in control. The lowest numbers of adult emergence $(11.11 \%)$ was obtained in black pepper at 1.00 $\mathrm{g} / \mathrm{kg}$ followed by black pepper $0.50 \mathrm{~g} / \mathrm{kg}$, black cumin 1.00 $\mathrm{g} / \mathrm{kg}$ and garlic $1.00 \mathrm{~g} / \mathrm{kg}$ of gram seeds. Significant reduction in oviposition performance and emergence revealed the toxic effect of the spices power towards the pulse beetle eggs. These results supported by the reports of Chaubey [28] and Miah [29] who observed that the black pepper was effective in reducing adult's emergence. The possible reason could be that the active components of the spice might have affected the physiology of the beetle.

\subsection{Effect of Spices Powder on Seed Weight Loss (\%) of Gram Seeds}

Table 2. Effect of spices powder on the gram seed weight loss (\%) caused by pulse beetle.

\begin{tabular}{|c|c|c|}
\hline Spices & Doses $(\mathrm{g} / \mathrm{kg})$ & Seed weight loss $(\%)$ \\
\hline \multirow{3}{*}{ Black pepper } & 0.25 & 32.201 \\
\cline { 2 - 3 } & 0.50 & 31.101 \\
\cline { 2 - 3 } & 1.00 & $29.00 \mathrm{~m}$ \\
\hline \multirow{4}{*}{ Black cumin } & 0.25 & $41.0 \mathrm{j} \mathrm{j}$ \\
\cline { 2 - 3 } & 0.50 & $39.70 \mathrm{j}$ \\
\cline { 2 - 3 } & 1.00 & $35.00 \mathrm{k}$ \\
\hline \multirow{3}{*}{ Methi } & 0.25 & $65.00 \mathrm{~d}$ \\
\cline { 2 - 3 } & 0.50 & $62.00 \mathrm{e}$ \\
\cline { 2 - 3 } & 1.00 & $55.00 \mathrm{~h}$ \\
\hline \multirow{3}{*}{ Garlic } & 0.25 & $52.30 \mathrm{~g}$ \\
\cline { 2 - 3 } & 0.50 & $49.70 \mathrm{j}$ \\
\hline & 1.00 & $42.00 \mathrm{i}$ \\
\hline Control & ---- & $77.10 \mathrm{a}$ \\
\hline
\end{tabular}

Means having different letter(s) within the column are significantly different at $\mathrm{P}<0.01$ by DMRT

Upon hatching the larvae chewed into seeds directly below the eggs. The life cycle was completed into a single seed and finally the beetle came out from the seeds by making a circular emergence hole. The weight losses were caused by feeding of larva inside the seeds. The effect of doses of black pepper, black cumin, garlic and methi powder on seed weight loss by the attack of pulse beetle was 
statistically significant and showed that the seeds weight loss was inversely proportional to the doses of spice powder (Table 2). The lowest amount of weight loss $(29.00 \%)$ was found in gram seeds with black pepper powder at $1.00 \mathrm{~g} / \mathrm{kg}$. The highest weight loss was observed in control (77.10\%). Minimum grain loss was noted with black pepper@1.00 $\mathrm{g} / \mathrm{kg}$, the possible reason might be the early mortality and less ovipositional and emergence performance. Aslam [5] found lower weight loss when chickpea was treated with clove and balck pepper extract.

\section{Conclusion}

Among the four spices, black pepper showed the highest toxicity against pulse beetle. It can be concluded that spices served as an environmental friendly and safer means of grain protectant against pulse beetle in stored gram. Further research can be done for the isolation of the toxic chemicals within black pepper to assess the toxicity.

\section{REFERENCES}

[1] B. B. S. (Bangladesh Bureau of Statistics). Statistical Year Book of Bangladesh. Bangladesh Bureau of Statistics, Statistics Division, Ministry of Planning, Government of People's Republic of Bangladesh. p.123, 2010.

[2] S. S. Sherma. Review of Literature of the losses caused by material as grain protectants against insect pests of stored Callosobruchus species (Bruchidea: Coleopetra) during storage of pulses. Bulletin of Grain Technology. Vol.27, 26-32, 1989.

[3] J. D. Demanyk, N. D. G. White, D. S. Jayas. Storage of chickpea. In: S.S. Yadav, R. Redden, W. Chen, B. Sharma, editors. Chickpea Breeding and Management, CAB International, pp. 538-554, 2007.

[4] H. C. Sharma, C. L. L. Gowda, P. C. Stevenson, T. J. Ridsdill-Smith, S. L. Clement, G. V. R. Rao, J. Romies, M. Miles, M. El Bouhssini. Host plant resistance and insect pest management. In: S.S. Yadav, R. Redden, W. Chen, B. Sharma, editors. Chickpea Breeding and Management, $\mathrm{CAB}$ International. pp. 520-537, 2007.

[5] M. Aslam, K. A. Khan, M. Z. H. Bajwa. Potency of some spices against Callosobruchus chinensis L. OnLine Biologica. Vol.2, No.7, 449-452. 2002.

[6] G. K. Ketoh, H. K. Koumaglo, I. A. Glitho. Inhibition of Callosobruchus maculatus (F.) (Coleoptera: Bruchidae) development with essential oil extracted from Cymbopogon schoenanthus L. Spreng. (Poaceae), and the wasp Dinarmus basalis (Rondani) (Hymenoptera: Pteromalidae). Journal of Stored Product Research.Vol 41, 363-371, 2005.

[7] M. Raja, W. S. John, M. Jayakumar. Repellent activity of plant extracts against pulse beetle Callosobruchus maculatus (Fab.) (Coleoptera: Bruchidae). Hexapoda Vol.14, 142-145, 2007.

[8] G. T. Gugar and T. D. Yadav. Feeding of Callosobruchus maculates and Callosobruchus chinensis Linin. in green gram. Indian Journal of Entomology. Vol. 40, 108-112, 1978.

[9] M. Loganathan, D. S. Jayas, P. G. Fields, N. D. G. White. Low and high temperatures for the control of cowpea beetle, Callosobruchus maculatus (F.) (Coleoptera: Bruchidae) in chickpeas. Journal of Stored Product Research. Vol.47, 244-248, 2011.

[10] K. C. Kim, H. C. Choi. Effect of temperature on the oviposition, feeding and emergence of the azuki bean weevil, Callosobruchus chinensis L. in the stored bean. The Review of Applied Entomology. Vol.77, No.10, 892, 1989.

[11] P. Purohit, D. S. Jayas, B. K. Yadav, V. Chelladurai, P. G. Fields, N. D. G. White. Microwaves to control Callosobruchus maculatus in stored mung bean (Vigna radiata). Journal of Stored Product Research Vol.53, 19-22, 2013.

[12] M. J. Haque, W. Islam. Effect of adult feeding on progeny production and sex ratio of Dinarmus basalis (Rond.) (Hymenoptera: Pteromalidae). Journal of Bioscience. Vol. 19, 77-80, 2011.

[13] M. Jacobson. Chemical insect attractant and repellents. Annual Reviewof Entomology.Vol.11, 403-423, 1966.

[14] G. Jilani, R. C. Saxena, B. P. Rueda. Repellent and growth inhibiting effects of turmeric oil, sweet flag oil, neem oil and Margosan-O on red flour beetle, Tribolium castaneum (Coleoptera: Tenebrionidae). Journal of Economic Entomology. Vol.81, 1226-1230, 1988.

[15] E. Shaaya, V. Ravid, N. Paster, B. Juven, U. Zisman, V. Pissarerw. Fumigant toxicity of essential oils against four major stored product insects. Journal Chemical Ecology 17: 499-504, 1991.

[16] A. Prakash, J. Rao. Use of chemicals as grain protectants in storage ecosystem and its consequences. Bulletin of Grain Technology. Vol.25, 65-69, 1987.

[17] G. Michael, S. Ahmed, W. C. Mitchel, J. W. Hylein. Plant species reportedly possessing pest control properties, An EWC/UH DATA BASE. University of Hawaii. p -249 , 1985.

[18] D. K. Weaver, F. V. Dunkle, L. Ntezurubanza, L. L. Jackson, D. T. Stock. Efficacy of linalool, a major component of freshly milled Ocimum canum Sims (Lamiaceae) for protection against post harvest damage by certain stored product coleopteran. Journal of Stored Product Research Vol.27, 213-220, 1991

[19] H. A. S. Mahdi, M. K. Rahman. Insecticidal effect of some spices on Callosobruchus maculatus (Fabricius) in black gram seeds. University journal of zoology, Rajshahi University. Vol.27, 47-50, 2008.

[20] O. Awoyinka, I. Oyewole, B. Amos, O. Onasoga. Comparative pesticidal activity of dichloromethane extracts of Piper nigrum against Sitophilus zeamais and Callosobruchus maculatus. African Journal of Biotechnology. Vol.5, 2446-2449. 2006.

[21] I. Scott, N. Gagnon, L. Lesage, B. Philogene, J. Arnason. Efficacy of botanical insecticides from Piper species (Piperaceae) extracts for control of European chafer (Coleoptera: Scarabaeidae). Journal of Economic 
Entomology. Vol.98, 845-855. 2005.

[22] I. M. Scott, H. Jensen, R. Nicol, L. Lesage, R. Bradbury. Efficacy of Piper (Piperaceae) extracts for control of common home and garden insect pests. Journal of Economic Entomology. Vol.97, 1390-1403, 2004.

[23] I. M. Scott, B. V. Helson, G. M. Strunz, H. Finlay, P. E. Sanchez-Vindas, L. Poveda, D. B. Lyons, B. J. R. Philogène, J. T. Arnason. Efficacy of Piper nigrum (Piperaceae) extract for control of insect defoliators of forest and ornamental trees. The Canadian Entomologist. 139: 513-522, 2007.

[24] T. Chieng , Z. Assim, B. Fasihuddin. Toxicity and Antitermite activities of the essential oils from Piper sarmentosum. Malaysian Journal of Analytical Science. Vol.12, 234-239, 2008.

[25] M. K. Chaubey. Insecticidal activity of Trachyspermum ammi (Umbelliferae), Anethum graveolens (Umbelliferae) and Nigella sativa (Ranunculaceae) essential oils against stored product beetle Tribolium castaneum Herbst (Coleoptera: Tenebrionidae). African Journal of Agricultural Research. Vol.2, 596-600, 2007.
[26] P. Jerome, P. M. Jesus, R. Catherine. Effects of material and extracts of Trigonella foenum-graecum $\mathrm{L}$. against the stored product pests Tribolium castaneum (Herbst) (Coleoptera: Tenebrionidae) and Acanthoscelides obtectus (Say) (Coleoptera: Bruchidae). Jounal of Stored Product Research Vol. 33, No.3, 209-217, 1997.

[27] N. B. K. Murthy, S. V. Amonkar. Effect of a natural insecticides from garlic (Allium sativum L.) \& its from (diallyl-disulphide ) on plant pathogenic fungi. Indian Journal of Experimental Biology. Vol.12, No.2, 208-209, 1974.

[28] K. M. Chaubey. Fumigant toxicity of essential oils from some common spices against pulse beetle, Callosobruchus chinensis (Coleoptera: Bruchidae). Journal of Oleo Science. Vol.57, No.3, 171-179. 2008.

[29] M. R. U. Miah, M. Elias, G. S. Torfder, B. N. Islam, M. A. Sarder, M. A. Karim. Evaluation of local plant material against the pulse beetle Callosobruchus chinensis (L.) on chickpea. Bangladesh Journal of Zoology. Vol.21, No.2, 151-153, 1993. 